УДК 81'282

https://doi.org/10.31548/philolog2020.03.006

\title{
DICTIONARY OF VARIANT VOCABULARY IN THE LIGHT OF MONOGRAPHIC DESCRIPTION: THEORETICAL JUSTIFICATION
}

\author{
T. V. HROMKO, PhD in Philology, Associate Professor, \\ Volodymyr Vynnychenko Central Ukrainian State Pedagogical University \\ E-mail: hromkot@gmail.com \\ https://orcid.org/0000-0002-4661-4302
}

\begin{abstract}
The article theoretically substantiates the Dictionary of variant vocabulary of a separate idiom as a particular aspect dictionary in a monodialect lexicographic complex. Nowadays, in the field of dialectology, word variability is explained by incompleteness or lack of empirical basis, failure to master the available factual material, insufficient attention to ways of studying formal modifications of the word, poor coverage of source and methodological issues. The urgency of the problem is determined by a number of theoretical provisions: 1) variability, being an immanent property of any kind of language, is widely represented in dialectal speech; 2) formal variation of the word ensures the continuity of speech as a system of language; 3) the lexicon of the dialect, the dialectolingual, is an information-research lexicographic system of the idiom - the thesaurus. A generalized review of the theoretical foundations of the dialectological lexicography of the variant vocabulary of the dialect allowed us to conclude about the specifics of the presentation of the dialect linguistics in it. The results of the research represent the Dictionary of variant vocabulary of speech as an aspect one, which is a part of a monodialect lexicographic complex, having unified rules of demonstration of language units and at the same time differing in its structural and nomenclatural parameters of lexical-semantic variations of language units. The dictionary of variant vocabulary of speech is seen by us as a representative of complexity, diversity of the phenomenon of formal variation of a dialect word, as a demonstration of a number of formalsemantic connections in vocabulary for further monodialect description focused on monographic description of speech. Lexicography of materially oscillating vocabulary within one idiom in the future is focused on the consideration of the peculiarities of word variation in the system of speech as a separate stratum of language.
\end{abstract}

Key words: dialectology, lexicology, lexicography, Dictionary of variant vocabulary of speech, variance, idiom, speech linguistics, idiomem.

Formulation of the problem. The problem of identity and variation of the word has an interdisciplinary nature and theoretically and in practice touches on various clusters of scientific knowledge about language: lexicology, lexicography, history of language, sociolinguistics, stylistics, language culture and more. Dialectology in this sense contributes to the development of theoretical and methodological and factual foundations of variantology as a linguistic direction, as the forms of manifestation of word variability in the dialect continuum of a particular language are extremely diverse; determining their status of lexical identity / variance is a systematizing principle, and "ultimately the theory of identity and word variation underlies the understanding of the word as a unit of language system" [16, p. 22], what is the ontological understanding of the idiom as a theoretical basis of linguistic scientific knowledge.

Analysis of recent research and publications. By the beginning of the XXI century. in linguistics there was still a difference in the interpretation of the word boundary, but the theoretical generalization of the principles of word modification is not possible without the empirical basis of its study [10, p. 5], which is practically provided by compiling dictionaries of different types and genres. In almost all dialectal lexicographical editions, word variants are presented as synonyms for literary ones within one article with appropriate references. However, the idea of creating separate dictionnaries of variant vocabulary of literary language (for example, normativestylistic dictio-nary that could be used in ligvodidactics) or a certain dialect formation with the fixation of "the widest possible variability in ways of expression" [12, p.88], unfortunately, still remains unrealized not only in Slavic linguistics, but in domestic.

Setting objectives. The solution of the problem of identity and word variation in dialectology can be facilitated by lexicological study of the idiom on a systematizing principle, 
and "ultimately the theory of word identity and variation underlies the understanding of the word as a unit of language system" [16, p. 22], which, in fact, is the ontological understanding of speech. Theoretical substantiation of the dictionary of variant vocabulary of a separate idiom will help to clarify the conclusion of the Consolidated scientific dialect dictionary of variant formations on the material of all Ukrainian dialect lexicography and other lexical and textual corpora according to the linguistic criterion of word identity / variance. Such a dictionary could integrate disparate facts into the common theory of identity / variance, illustrating clearly the material for typological research in the field of phonetics, vocabulary, word formation, morphology [8, p. 48], as well as for the comparative and historical study of Slavic languages and their dialects.

Presenting of the main material. Dialect material consists of variant units, which are characterized by both the number and variety and individuality of expression in a separate system of idioms, in addition, do not exclude literary usage. In local dialect lexicographical editions there is a tradition to present variants of words within one vocabulary (eg, [1], [5], [14]). Enriched with variant units of the Ukrainian dialect language, the experience of M. Tkach's "Dictionary of dialect, colloquial, rarely used and obsolete words of the Ukrainian language" [17] "suggests" that in Ukrainian dialectology it is time to compile a Consolidated Scientific Dialect Dictionary of Variant Formations dialect lexicography and other lexical and textual corpora. Such a dictionary could integrate disparate facts into the common language theory of identity / variance, illustrating material for typological research in phonetics, vocabulary, word formation, morphology, and for the comparative-historical study of Slavic languages and their dialects. "Work on a consolidated dialect dictionary of variants," writes Y. Golovin, planning at one time a Russian consolidated dialect dictionary of variant formations on the basis of the "Dictionary of Russian Folk Dialects," would serve to unify as yet uncoordinated lexicographic experiments and help develop unified scientific theoretical and practical bases of vocabulary development of variant units of language" [9, p. 85].

In Ukrainian studies, such a consolidated dictionary would demonstrate variants of word connections on the material of the lexical system of the Ukrainian dialect language as a manifestation of its homologous asymmetry.
Focused on the study of material fluctuations of the word, not in the spatial (areal) aspects of language (see [10]), but in the practical aspect, the dictionary of variant dialect vocabulary is a representative of formal (external, material) modification of the word in terms of variantology.

The variability of language as a system, and hence of individual dialects, is characterized by poor learning. According to the theory of identity and difference of the word, a formal modification of the word, the theoretical foundations of which are formulated in the works of V. Vinogradov [6], A. Smirnitskiy [15], O. Akhmanova [2] in Slavic studies, German studies, Turkology. etc., being an immanent property of any kind of language, widely represented in dialectal speech [3, p. 4].

Meanwhile, the special role of variant units, including formal modifications of the word, is such an essential property of language that it cannot be limited to the analysis of individual facts or groups of facts at different levels of the language system, but should be studied in variantology [7]. Word variation is a fundamental property of any language, an absolute linguistic universal. It is a kind of plexus of complex relationships between different language levels, a reflection of trends in language development.

Studies on the variation of a dialect word show, as a rule, fragments of this phenomenon, which are separate groups of words, such as unstable in sound, areal features of lexical variants [10]. The interest of scholars is often aimed at studying the formal variation of the word as a phenomenon of dialectal macrosystem - a group of related or typologically similar dialects. "Modern leading positions of the functional paradigm, - says Z. Bogoslovskaya, - encourages the shift of emphasis to the study of formal modifications of the word, which actually interact in one idiom" $[3$, p. 5]. For example, variant vocabulary in literary language differs from dialectal in terms of formal modifications and motivation of the word, the relationship between lexicalization and material modification, and so on. Nowadays, in the field of dialectology, word variability is explained by incompleteness or lack of empirical basis, failure to master the available factual material, insufficient attention to ways of studying formal modifications of the word, poor coverage of source and methodological issues.

Solving problems of formation and development, tools of variantology or generalization of the experience in classifying 
types of formal variants, methods, principles and criteria of identification, taxonomy of formal variation of words in speech are not set by us as tasks within dialectological research. Such problems can be solved only under the condition of completeness of the empirical basis of the usus, the description of which is aimed at such explorations of variantology as the word phenomenon.

To describe the dialect, it is necessary to present a complete variant dictionary of the dialect, to clarify the ontological features of the formal variation of the word, outlining the status of this type of work, taking into account the contribution of predecessors. Lexicography of materially oscillating vocabulary within one idiom in the future is focused on the consideration of the peculiarities of word variation in the system of speech as a separate stratum of language. Such representativeness of factual material will not only empirically enrich Ukrainian dialectology, but also, focused on a monographic description of the dialect, will ensure the objectivity of a number of other Ukrainian and Slavic linguistic studies.

Covering a significant layer of vocabulary of each type of language [4, p. 3], word variation represents the immanent properties of speech. Formal variance of the word is particularly productive in oral dialectal speech. Our previous explorations in this regard [18] confirm the presence in the language of the formal-semantic type of word variation with formal-semantic paradigms of words (synonyms, paronyms) and form a formal-semantic paradigm in the vocabulary. According to Z. Bogoslovskaya's research, "formal word variation acts as a condition of continuity in the space of communicative function of language, therefore one of the main features of variant vocabulary of dialect language system is its characteristic in terms of correlation with basic forms of national language" [3, p. 9].

Variantology of dialect language in the applied aspect - tools (principles, methods, sources, etc.), lexicographic parameterization of formal modifications of the word is properly described in the Russian "Dictionary of variant vocabulary of the Siberian language" [4]. This new type of dialect dictionary of the system type includes a theoretical part, a methodical tool and a source base of variantology of the well-known full and a number of aspect dictionaries of the Russian dialect of Vershynino village. This is a differentiated characteristic of different aspects of variantology of speech (units, properties, process), application of different principles of analysis (discreteness / indiscretion, anthropocentrism, etc.) and a set of criteria (semantic, material, structural, functional, cognitive, etc.) and their ranking. [3, p. 9] demonstrates a comprehensive delineation of the formal variability of the word as a multidimensional structure.

Objective representation of the subject of research - the variant vocabulary of speech - is possible nowadays when qualifying units of expression as simple (binary oppositions) and complex (two-membered and polynomial opposition) word paradigm, as fragments of an open complex, hierarchically structured, systematically organized association. Z. Bogoslovskaya names as "a field of formalsemantic type" [3]. At the dialectal level, formal word variation is a distinctive feature of a large array of words relative to a lexicon with a stable form.

As an essential attribute of dialectal language, formal word variation characterizes the expression of variant connections of lexical units for different purposes, which is realized in different genres of dialectal speech, and along with expressiveness and other features, is rightly recognized as a phenomenon of folk language culture. Any dialect can be described immanently, as the language of a particular society, in the ways developed by modern linguistics.

One of the most fundamental features of the formal variation of a word is the possibility of manifesting changes in it in a separate stratum at the synchronous level. The description of speech is revealed through the phonetic, morphological, word-changing and word-forming potential of language, which is fixed in formal variants of the word, reflecting in them all the variety of language processes, tendencies, trends, etc.

According to researchers, the nature of the formal variation of the word "can be defined as dual: definite and blurred, stable and temporary, typical and unique, real and potential, ballast and multifunctional, common and local, usual and individual, own and foreign, etc. [3, p. 12].

Formal variation of the word ensures the continuity of speech as a language system [13, p. 24], and thus is the main condition for the continuity of the communicative function of language in time and space, the relationship between sociolect and idiolect. Since the principles of the dialectological paradigm are function, language system, structural unit of the idiom (speech), the vision of speech as a holistic multilevel unit and requires a detailed study of all mono-verbal elements, including word variants, for a comprehensive comprehensive study - a monographic description of speech.

The result of the study of the dialectological 
lexicography of the variant vocabulary of speech is based on the complete description of speech is the lexical representation according to the thesaurus of speech spoken by us, based on the monodialect corpus of texts. This is the main segment of speech lexicography or a fragment of descriptive lexicography of speech, which focuses on other aspect dictionaries of speech. The whole set of words of the dialect, the dialect-lingual, is part of the monodialect lexicographic complex. Such an information-research lexicographic system is able to reflect the real language situation of a particular usus.

The peculiarities of the microstructure of the Dictionary of variant vocabulary among the main composition of dictionaries include the specifics of design based on the thesaurus of speech, as well as structural and nomenclature parameters of lexical and semantic changes of language units.

Unified rules for the demonstration of units of such a plan:

- selection of word variants and features of lexicography of its formal variants, of course, demonstrates the presence of regular structural and semantic types in this area;

- a number of criteria which are used to establish the affiliation of variable units to one paradigm of the word, among which it is impossible not to take into account the indicators of metalanguage consciousness of native speakers within their usage;

- the speech thesaurus does not provide for the placement of variant formations within a single dictionary article. Attribution of all word variants in the dictionary of variant vocabulary of the dialect is a basic condition for detailed "portrayal" of each of the elements of the formal word variant.

The dictionary of variant vocabulary of the dialect by typological characteristics is monodialectal, microsystemic, usual, verbal, nondifferential, synchronous, partial (reflects a fragment of the lexicon), systemic, variant, semasiological, linguistic interpretive-aspect, descriptive, linguistic-centric arrangement, and material solid, straight [3, p. 16].

Among the linguistic parameters of this type of dictionary are phonetic-grammatical, semantic, pragmatic, illustrative (macro- and microcompositional). Implementing the idea of the lexicographic monodialect monographic description, the dictionary of variant vocabulary of the dialect at the same time extrapolates the

\section{Список використаної літератури}

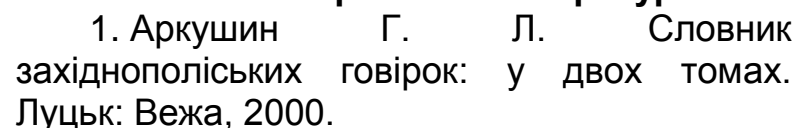

specifics of dialectal variability as an aspect dictionary of a new type, which is designed to demonstrate numerous systemic (intraverbal) connections, which is the prerogative of dialectal speech as a phenomenon. Variant dialect data will allow solving a number of general theoretical problems related to the problems of word identity, lexicalization of phonetic and morphological processes, comparative-typological research, etc.

A component of a monodialect lexicographic complex, which describes the vocabulary of one dialect system in full and from different angles, the dictionary of variant vocabulary of the dialect is created to perform the descriptive function of language units as an expressive resource of dialect usage.

The dictionary of variant vocabulary of the dialect is seen by us as a representative of complexity, the diversity of the phenomenon of formal variation of a dialect word, as a demonstration of a number of formal-semantic connections in the vocabulary for further monodialect description, focused on a monographic description of speech (combining them on the principle of functional commonality, for example linguistic units, and linguistic - on the lexical-semantic principle), because for a descriptive lexicographic description is sufficient only the primary linguistic isolation of idioms - the smallest phenomena - (by our definition, the triad "speech - dialect phenomenon" is an idiom); about this see [11]).

A novelty in such a variable aspect of lexicography is the inclusion of various onomastic material. The main complex of the dictionary unites all categories of onyms, which gives the opportunity to explore the whole complex of information with this facet of the dialect.

Conclusions and suggestions. $A$ generalized review of the theoretical foundations of the dialectological lexicography of the variant vocabulary of the dialect allowed us to conclude about the specifics of the presentation of the dialect linguistics in it. The dictionary of variant vocabulary of the dialect is presented by us as a representative of complexity, diversity of the phenomenon of formal variation of a dialect word, as a demonstration of a number of formal-semantic connections in the vocabulary for further monodialect description focused on monographic description of dialect.

2. Ахманова О.С. Очерки по общей и русской лексикологии. Москва: Учпедгиз, 1957. 295 c.

3. Богословская 3. М. Диалектная вари- 
антология: лексикологический и лексикографический аспекты: дис. ... доктора фрилол: 10.02.01 / Том. гос. ун-т. Томск, 2006. 401 с.

4. Богословская 3. М. Словарь вариантной лексики сибирского говора. Т. 1: А-К /Под ред. О.И. Блиновой. Томск. Томский государственный университет, 2000. 304 c.

5. Бондар О.І. Словник українських говорів Одещини. Одеса: Одеський національний університет ім. І. І. Мечникова, 2010. 222 c.

6. Виноградов В. В. О формах слова. Известия АН СССР. Отделение литературы и языка. Москва, 1944. Т. III. Вып. 1. С. 31-44.

7. Гак В.Г. Языковые преобразования. Москва: Школа «Языки русской культуры», 1998. $768 \mathrm{c.}$.

8. Глуховцева К. Варіативність діалектних явищ, у системі українських східнослобожанських говірок. ВолиньЖитомирщина. 2005. № 14. С. 48-54.

9. Головина Э. В. Формальная вариантность в речи диалектного типа: Учеб. пособие по спецкурсу. Киров, 1991. 102 с.

10. Гриценко П. Ю. Ареальне варіювання лексики. Київ, 1990. 272 с.

11. Громко Т. Система говіркових явищ в монодіалектних описах. Науковий вісник Східноєвропейського національного універcumemу імені Лесі Українки. Серія: Філологічні науки. Луцьк, 2020. Вип. 3(407). C. 24-28.

12. Иванцова E. В. Отражение варьирования слова в диалектных словарях. Русские говоры Сибири. Лексикография. Томск: Изд-во Том. ун-та, 1993. С. 87-91.

13. Мельничук О. С. Розвиток мови як реальної системи. Мовознавство. 1981. № 2. C. 22-34.

14. Сабадош І. В. Словник закарпатської говірки села Сокирниця Хустського району. Ужгород: Ліра, 2008. 480 с.

15. Смирницкий А. И. К вопросу о слове (проблема «тождества слова»). Труды Института языкознания. Москва, 1954. T. 4. C. 3-50.

16. Соколов О. М. Основы имплицитной морфологии русского языка. Москва: Изд-во «РУДН», 1997. 203 с.

17. Ткач М. М. Словник говіркових, розмовних, рідковживаних та застарілих слів української мови. Чернігів : ПАТ «ПВК «Десна», 2019. 1000 c.

18. Hromko T. V. Theoretical fundamentals of lexicographic variation of idiom. Korszerü müszerek és algoritmusa tapasztalati és elméleti tudományos kutatási: tudományos müvek gyüjteménye a nemzetközi tudományosgyakorlati konferencia anyagaival (Hang 3), September 18, 2020. Budapest, Hungary: European Scientific Platform. P. 63-64.

\section{References}

1. Arkushyn, H. L. (2000), Slovnyk zakhidnopoliskykh hovirok [Dictionary of Western Polissya dialects]: u dvokh tomakh. Lutsk: Vezha.

2. Akhmanova, O.S. (1957), Ocherki po obshchey i russkoy leksikologii [Essays on general and Russian lexicology]. Moskow: Uchpedgiz. 295.

3. Bogoslovskaya, Z. M. (2006), Dialektnaya variantologiya: leksikologicheskiy $\mathrm{i}$ leksikograficheskiy aspekty [Dialectal variantology: lexicological and lexicographic aspects]: dis. ... doktora filol.: 10.02.01 / Tom. gos. un-t. Tomsk. 401.

4. Bogoslovskaya, Z. M. (2000), Slovar variantnoy leksiki sibirskogo govora. [Dictionary of the variant vocabulary of the Siberian dialect]. T. 1: A-K / Pod red. O. I. Blinovoy. Tomsk. Tomskiy gosudarstvennyy universitet. 304.

5. Bondar, O. I. (2010), Slovnyk ukrainskykh hovoriv Odeshchyny. [Dictionary of Ukrainian dialects of Odessa region]. Odesa: Odeskyi natsionalnyi universytet im. I. I. Mechnykova. 222.

6. Vinogradov, V. V. (1944), O formakh slova [About the Word Forms]. Izvestiya AN SSSR. Otdeleniye literatury $i$ yazyka [News of the USSR Academy of Sciences. Department of Literature and Language]. Moskow:. (III/1). 31-44.

7. Gak, V. G. (1998), Yazykovyye preobrazovaniya [The Language Conversions]. Moskva: Shkola "Yazyki russkoy kul'tury». 768.

8. Hlukhovtseva, K. (2005), Variatyvnist dialektnykh yavyshch u systemi ukrainskykh skhidnoslobozhanskykh hovirok [Variability of dialect phenomena in the system of Ukrainian East Slobozhansk dialects]. Volyn'Zhytomyrshchyna [Volyn-Zhytomyr region]. (14). 48-54.

9. Golovina, E. V. (1991), Formal'naya variantnost' $v$ rechi dialektnogo tipa: Ucheb. posobiye po spetskursu [Formal variance in dialect-type speech: A textbook for a special course]. Kirov. 102.

10. Hrytsenko, P. Yu. (1990), Areal'ne variyuvannia leksyky [The Areal Variation of Vocabulary]. Kyiv. 272.

11. Hromko, T. (2020), Systema hovirkovykh yavyshch $v$ monodialektnykh 
opysakh [System of speech phenomena in monodialect descriptions]. Naukovyi visnyk Skhidnoievropeiskoho natsionalnoho universytetu imeni Lesi Ukrainky. Seriia: Filolohichni nauky [Scientific Bulletin of the Lesia Ukrainka East European National University. Series: Philological Sciences]. Lutsk. (407/3). 24-28.

12. Ivantsova, Ye. V. (1993), Otrazheniye var'irovaniya slova $\mathrm{v}$ dialektnykh slovaryakh [Reflection of word variation in dialect dictionaries]. Russkiye govory Sibiri. Leksikografiya [Russian dialects of Siberia. Lexicography]. Tomsk: Izd-vo Tom. un-ta. 87-91.

13. Mel'nychuk, O.S. (1981), Rozvytok movy yak realnoi systemy [Development of language as a real system]. Movoznavstvo [The Linguistics]. (2). 22-34.

14. Sabadosh, I. V. (2008), Slovnyk zakarpatskoi hovirky sela Sokyrnyts'ia Khusts'koho raionu [Dictionary of the Transcarpathian dialect of the village of Sokyrnytsia, Khust district]. Uzhhorod: Lira. 480.

15. Smirnitskiy, A. I. (1957), K voprosu o slove (problema "tozhdestva slova») [On the question of the word (the problem of "word identity")]. Trudy Instituta yazykoznaniya [Studies of the Institute of Linguistics]. Moskva. (4). 3-50.

16. Sokolov, O. M. (1997), Osnovy implitsitnoy morfologii russkogo yazyka [Fundamentals of the implicit morphology of the Russian language]. Moskva: Izd-vo «RUDN». 203.

17. Tkach, M. M. (2019), Slovnyk hovirkovykh, rozmovnykh, ridkovzhyvanykh ta zastarilykh sliv ukrainskoi movy [Dictionary of dialect, colloquial, rarely used and obsolete words of the Ukrainian language]. Chernihiv: PAT «PVK «Desna». 1000.

18. Hromko, T. V. (2020), Theoretical fundamentals of lexicographic variation of idiom. Korszerü müszerek és algoritmusa tapasztalati és elméleti tudományos kutatási: tudományos müvek gyüjteménye a nemzetközi tudományos-gyakorlati konferencia anyagaival [Modern instruments and algorithms of experiential and theoretical scientific research: a collection of scientific works with the materials of the international scientific-practical conference]. September 18, 2020. Budapest, Hungary: European Scientific Platform. (3). 63-64.

\section{СЛОВНИК ВАРІАНТНОЇ ЛЕКСИКИ У СВІТЛІ МОНОГОВІРКОВОЇ ДЕСКРИПЦІЇ: ТЕОРЕТИЧНЕ ОБҐРУНТУВАННЯ}

\section{Т. В. Громко}

Анотація. У статті теоретично обгрунтовується Словник варіантної лексики окремого ідіому як окремий аспектний словник в монодіалектного лексикографрічного комплексу. У наш час у царині діалектології варіантність слова пояснюються неповнотою або відсутністю емпіричної бази, неосвоєнням наявного фрактичного матеріалу, недостатньою увагою до способів вивчення формальних модифрікацій слова, слабкою освітленістю джерелознавчих та методологічних питань. Актуальність проблематики визначає ряд теоретичних положень: 1) варіантність, будучи іманентною властивістю будь-якого різновиду мови, широко представлена в діалектному мовленні; 2) формальне варіювання слова забезпечує континуальність говірки як системи мови; 3) лексикон говірки, говірколінгварій, становить інформаційно-дослідницька лексикографрічна систему ідіому - тезаурус. Узагальнений огляд теоретичних засад діалектологічної лексикографрії варіантної лексики говірки дозволив дійти висновку про специфріку представлення в ньому говірколінгварію. Результати дослідження репрезентують Словник варіантної лексики говірки як аспектний, який входить до моноговіркового лексикографрічного комплексу, маючи уніфіковані правила демонстрації у ньому мовних одиниць і водночас відрізняючись своїми структурними та номенклатурними параметрами відображення лексико-семантичних видозмін мовних одиниць. Словник варіантної лексики говірки бачиться нами як репрезентант складності, різноманіття явища формального варіювання діалектного слова, як демонстрація цілого ряду фрормальносмислових зв'язків у лексиці для подальшої моноговіркової дескрипції, орієнтованого на монографрічний опис говірки. Лексикографування матеріально коливальної лексики в межах одного ідіому в перспективі орієнтоване на розгляд особливостей варіювання слова в системі говірки як окремого страту мови.

Ключові слова: діалектологія, лексикологія, лексикографрія, Словник варіантної лексики говірки, варіантність, ідіом, говірколінгварій, ідіомема. 